\title{
Eugène Atget and Documentary Photography of the City
}

\begin{abstract}
This paper focuses on the documentary photography of Eugène Atget in late 19th and early 20th century Paris. I will begin by exploring Atget's position as a pioneering documentary photographer in the field, followed by an engagement with the urban environment of Paris, in which Atget worked almost exclusively. Finally, I will analyse a single photograph in depth while discussing it in relation to the work of Charles Baudelaire and Jacques Rancière. This text is a contribution to a literature of critical engagement with documentary photography, urban history and the politics of class visibility. I will do so by arguing for the political significance of reading Atget's images in a critical, political manner that engages with Rancière's concept of the 'anonymous multiple'. Atget is considered a key documentary photographer, and, as such, he is exemplary of the history of documentary photography and its treatment of its subjects.
\end{abstract}




\section{Paris's Eugène Atget}

Out of photography, one can make passport pictures, weather photographs, pornographic pictures, X-rays, wedding pictures, and Atget's Paris.

(Sontag, 1979: 116)

Eugène Atget's work has a unique pioneering status in the domain of documentary photography. While most documentary photography at the time was focused primarily on architecture, Atget's work brought into focus both miniscule ornamental detail (i.e. of doors, statues, fountains, churches, etc), grand doorways of churches and palaces (incl. Versailles itself), and the newly built boulevards of Haussmann in Paris. Atget is a photographer who both documented what is lost, or in the process of disappearance, and captured the uncanny nature of the French metropolis in the late $19^{\text {th }}$ and early $20^{\text {th }}$ century. He did so in a manner that led photographers ${ }^{1}$, surrealist ${ }^{2}$ artists, and painters ${ }^{3}$ to recognise him as pioneering and influential. Being considered the 'first documentalist' (Vassallo, 2014: 23), as well as figuring in discourse at the centre of the domain's origin, his work is unsurprisingly ambiguous and rich in meaning. Atget's work is key to understanding the conjuncture of the modern city in its early form (see Rizov, 2020).

In Berenice Abbott's words (1964: vii), Atget 'gave photography its full potential as an art in its own right'. According to Walter Benjamin (2006: 258), '[w]ith Atget, photographic records begin to be evidence in the historical trial'. Atget's work became prominent in a period of photographic discourse where photography fitted into one of two styles - the pictorial or the documentary ${ }^{4}$. While Atget was clearly interested in practicing the latter, his use of the documentary style remained somewhat different from most photography produced at the time, and thus proved formative in the style itself. To quote Barthes's description of all photographs - Atget's work can be seen as particularly 'docile' (2001: 43). It was exactly at the time of Atget's rise in popularity that the use of captions became necessary in illustrated magazines (Benjamin, 2006: 258). This 'docility' is a quality of photographs that writers, Sontag (1979) and Sekula (2016) being most prominent among them, have referred to as a photograph's indeterminacy of meaning and the necessity of context for any kind of semiotics or hermeneutics. 
This indeterminacy of meaning is evident in Atget's work. The varying interpretations are multiple - he is attributed with feats such as being 'the first surrealist' or a proto-surrealist (Benjamin, 1979), creating the 'artistic document', being inherently modern and modernist, as well as being naïve (MacFarlane, 2010), ingenious, and/or craftsman-like (Nesbit, 1998). He is an intriguing figure to use as a case study, precisely due to the unanimity surrounding his position as a pioneer in the domain of documentary photography (for example, see Nesbit, 1992a; 1992b; Freund, 1980; Szarkowski, 1985; Benjamin, 1979; Kracauer, 1960).

Nesbit (1992b: 16), in her monograph on Atget, provides an early definition of the notion of document - it was given at the Fifth International Congress of Photography in Brussels in 1910 - in which:

a documentary image should be understood for studies of diverse kinds, ergo the necessity of including the maximum possible detail (in Nesbit, 1992: 16).

However, the term 'documentary' is usually cited as having only emerged in 1926, when the critic John Grierson used it in order to describe a film (Lugon, 2006); according to him (Grierson, 1966: 147), documentary is 'the creative treatment of actuality'. Since this definition, the meaning of the term has been applied easily and frequently to work that preceded Grierson, including photographers such as Eugène Atget ${ }^{5}$.

Atget remains a photographer, whose practice is unique in three distinct ways. First, he undertook a largescale project of more than 10,000 photographs taken for a period of over 30 years by his own initiative (Nesbit, 1998), only briefly taking commission (and often on his own terms - see Szarwkoski, 1985), and only selling his photographs as a freelancer (Nesbit, 1998; Hambourg and Szarkowski, 1982). Second, Atget is a figure of widely recognised pioneering status, with reputed photographers such as Berenice Abbott, Walker Evans, August Sander, Henri Cartier-Bresson citing his work as a primary influence (Szarkowski, 1982) - and with non-photographic figures such as Walter Benjamin (1979), Gisele Freund (1980), André Breton (Walker, 2002), and Georges Bataille (Durden, 2003) also lauding him as a key figure of the time. Third, he is continuously cited as reluctant to describe his photographs as artistic or artful, instead preferring the phrase 'documents for artists' (Walker, 2002). This last point, in conjunction with his numerous work and influential status, identifies him as a key figure in relation to the development of documentary photography in the city of Paris and Modernity as a whole. 
A somewhat underexplored aspect of Atget's work is his politics. Out of the multitude of monographs and treatises on Atget, it is only Nesbit (1998) that makes a brief comment on his left leanings in passing. Nesbit (1998) reports that he was a subscriber to 'the Socialist press' of his time. Warner (1993) further clarifies that Atget was subscribed to both La Guerre Social, an ultra-left and pacifist-anarchist newspaper founded by Gustave Hervé (see Loughlin, 2001), and Le Bonnet Rouge - an anarchist publication (Warner, 1993; also, see Loughlin, 2001). Atget also delivered lectures to working-class schools (Nesbit, 1998: 402), and, as a contemporary of the Dreyfus Affair, he 'collected a large dossier of press cuttings' on its development (Nesbit, 1998: 402). With this in mind, Atget was a 'passionate Dreyfusard' (Warner, 1993: n.p.). This, in turn, bears potential significance on Atget's representation of the city, since the areas he worked in would have been primarily working class. His political commitments would then imply an engagement with the people of the spaces he documents and their struggles. However, unlike the bourgeois leanings of the surrealist movement in Paris at the time, the anarchist leaning of Atget is currently absent in publications in the English language - despite meriting further exploration. Unfortunately, the scope of this article does not allow for this, but this remains an important context in which to see Atget's engagement with the streets of Paris and their inhabitants.

\section{Eugène Atget's Paris}

But Atget's work—and it must be looked upon as a whole-is the most remarkable photographic record of Paris ever created.

(Newhall, 1937: 66)

In this article, I intend to demonstrate that the plurality of discourse surrounding Atget's work is indicative of the new mode of representation of which he himself has become representative. In Hudgins' words (2013: 11), although applied to a different context, the appeal of Atget's work is the 'new sense of "camera vision"” that he was elaborating through a transformation of what might have, until that point, been considered 'unpicturesque' - doorways, balconies, ruins, and streetscapes devoid of people. The very way in which he approached the photographing of important landmarks, such as the Panthéon, have been noted as unconventional for its time (MacFarlane, 2010: 23). This note can easily be illustrated by comparing 
Atget's street view (figure 3 below) with that of his predecessors - Charles Marville (figure 2 below) and Pierre Emonts (figure 1 below). While both Marville and Emonts follow the perspectivising effect of the boulevard (Rizov, 2020), Atget's image differs considerably in its aesthetics. Atget relies on stark contrast, partial detail of buildings, heavy vignetting and dramatic framing in order to produce an image that appears odd - as if a composite of two photographs.

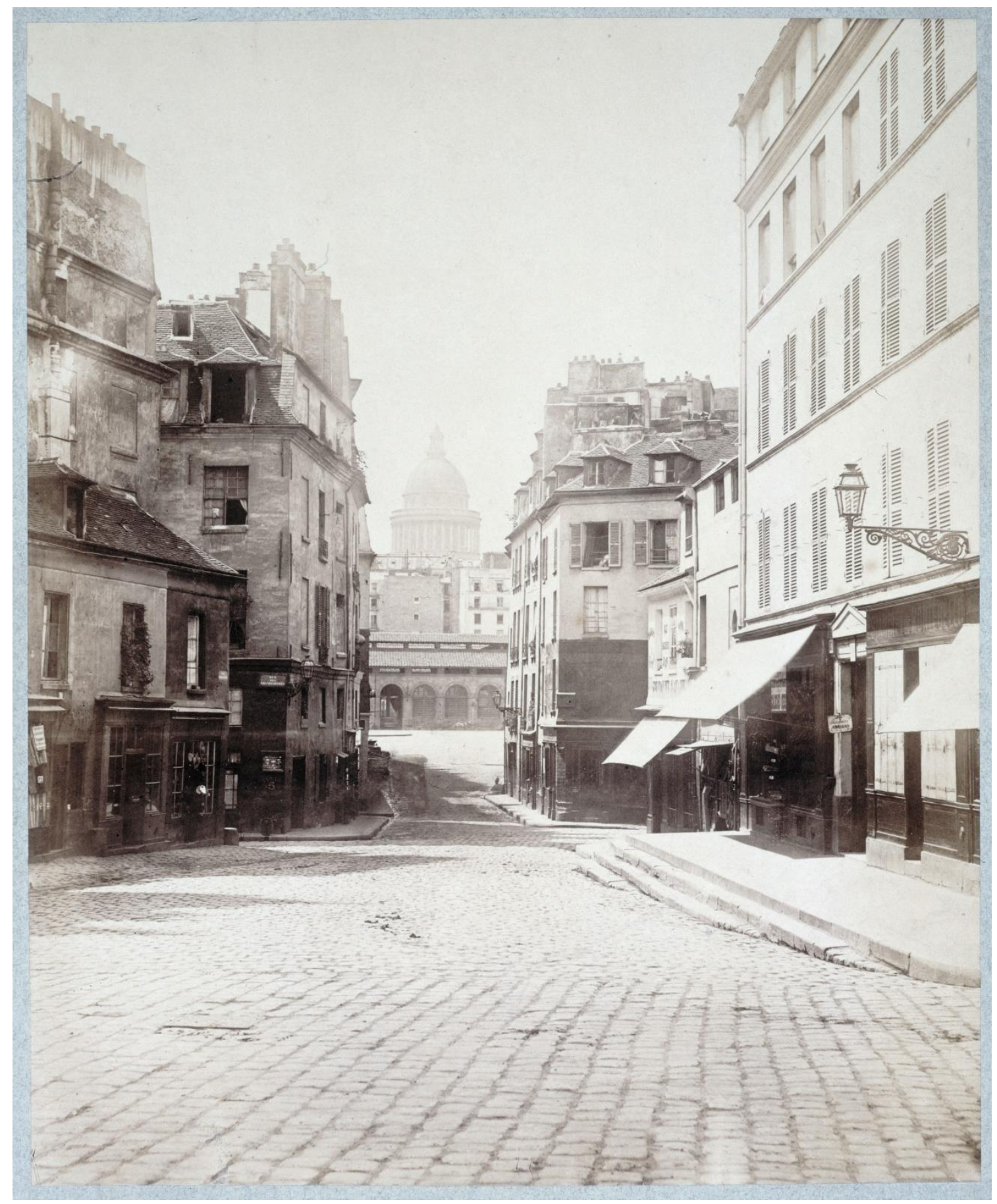

Figure 1 Rue du Haut-pavé by Pierre Emonts, CCØ Paris Musées/ Musée Carnavalet, 1869-1902. 


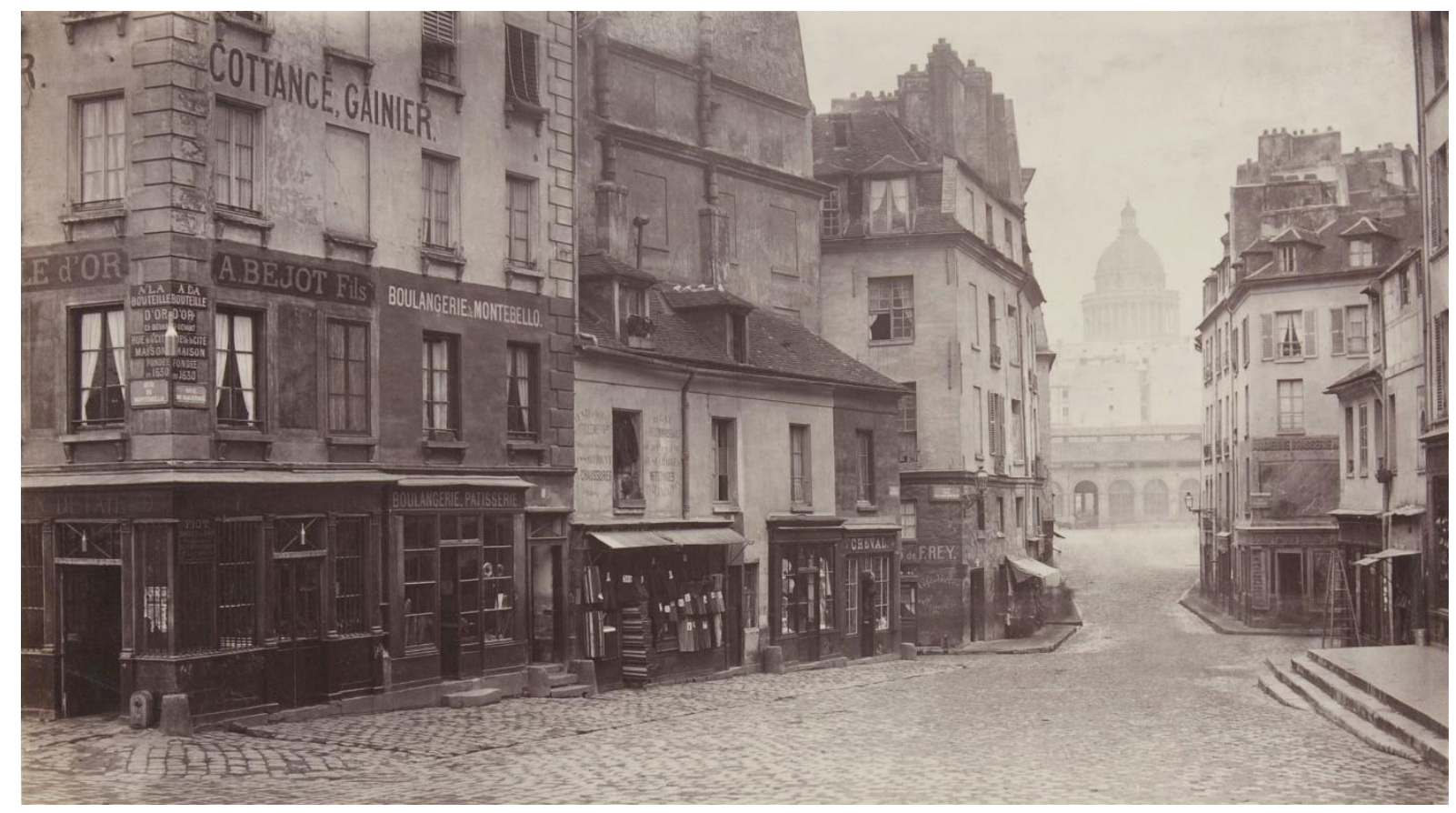

Figure 2 Rue du Haut-Pave (Pantheon in Distance) by Charles Marville, MET Museum/WikiCommons, 1865-69.

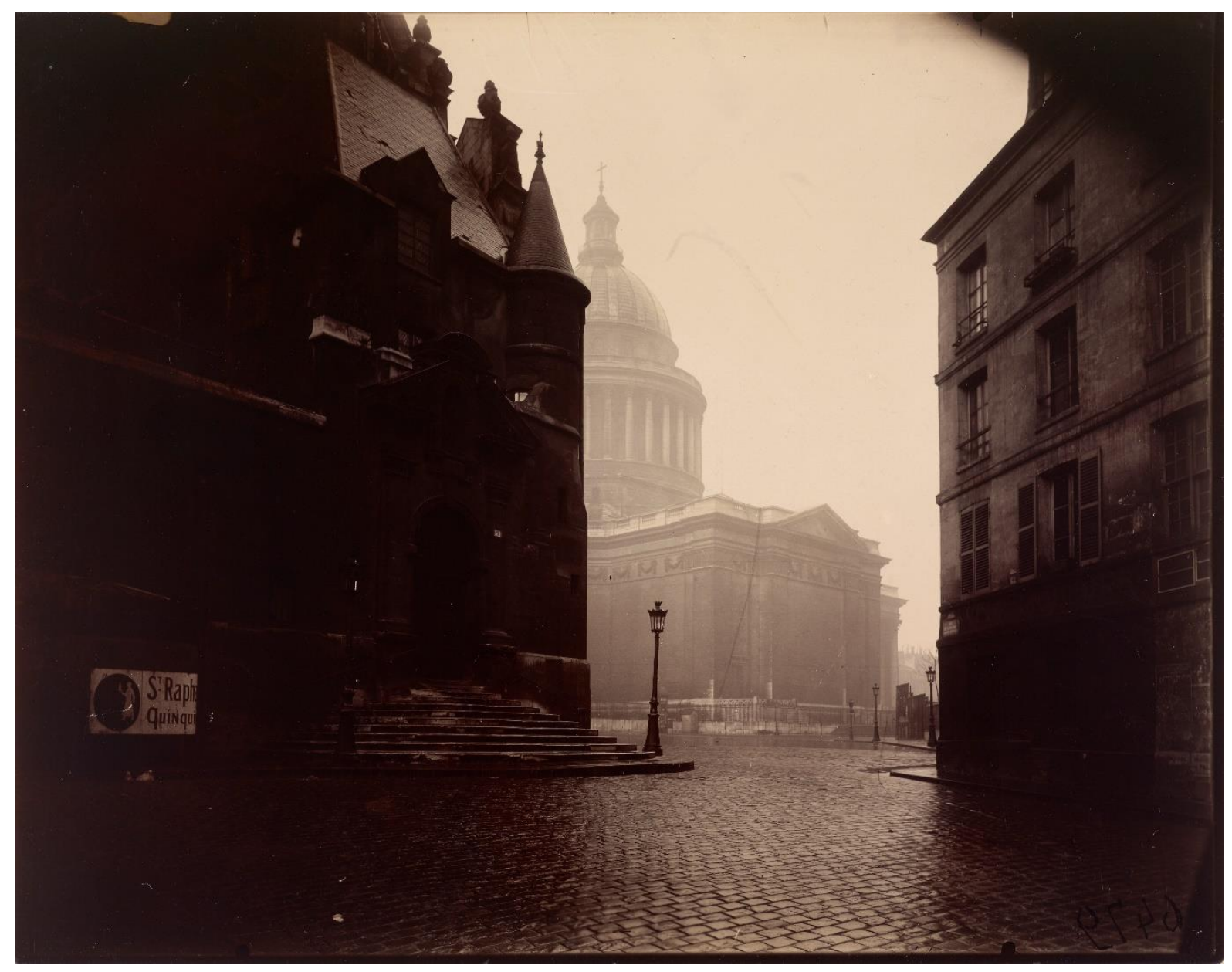

Figure 3 The Pantheon by Eugène Atget, Getty Museum/WikiCommons, 1924. 
A necessary qualification of Atget's work is the historical setting in which it occurred. The historical conjuncture in which Atget practiced photography is one of great urban change, commercialisation of the public spaces of Paris, and more particularly - the creation of a large network of thoroughfares consisting of wide boulevards lined with cabarets and salons (Huddleston, 1928), cafés (Haine, 1999), and department stores (Harvey, 2005). As Rubin (2008: 17) points out, this was also a period, in which Paris became 'the place where modern vision was developed' (also, see Rizov 2020). Architecture in Paris, during the period of Atget's practice, was central to the experience of the city - the old buildings would constantly be disappearing in order to make space for the new (Harvey, 2005). Moreover, photography and architecture have been in dialogue since the invention of photography (Perego, 1998). Perego (1998: 197) has referred to this as the role the modern photographer at the time played of 'mediator between the outside world (that is, the new fields of perception) and contemporary society'. Especially so, since, because of Haussmann's changes:

there arose the idea of a perfect match between the city and the photographic style with which it was documented, a style totally dedicated to the "cult of the axis" [exemplified by the boulevard] as the ordering principle of urbanism and this of the formal structure of the photographic approach (Perego, 1998: 199).

Literature on Atget's work often tends to emphasise the presence of multiple and varied elements of architecture in his photographs (see Nesbitt, 1998). Regarding an image called 'Cabaret au Tambour', Nesbit (1998: 408) has commented on the multiple layers of meaning inherent to the document that Atget produced:

There were signs for historians of Paris, who were interested only in the drum [tambour in French]; there were signs for metalworkers, looking to see just how the grille and sign had been made; and there were signs of modern life - the distorted figures in the doorway (emphasis in original).

Nesbit's description demonstrates the way Atget would produce documents that were targeted to more than one type of client; he would often simultaneously produce documents for 'artists, builders, set designers or historians' (Nesbit, 1998: 405). Clear examples of this would be exactly these elements of 
architecture being described so far - stairway railings, stonework doorways, or ornamented wrought-iron balconies. It is this that Nesbit (1998: 402) refers to as the document containing 'grains of knowledge that would $[\ldots]$ be used to produce more advanced knowledge'. Namely, the photographic documents that Atget produced were not only created for particular clients in mind (and often more than one type of client), but also for a particular type of reading that the intended client would likely exercise over the image. For example:

a document of old Paris would inform an antiquarian's account of a seventeenth century political event; a document from a lampshade salesman's catalogue might inform a genre painting meant for exhibition at the Salon and so on (Nesbit, 1998: 402).

Moreover, it is:

[Atget's] views of undistinguished facades, and of articles displayed outside or just inside storefronts, [that] were perhaps the first works of art to direct attention to the commercial (not industrial) environment in a completely artistic way - in a way, that is, which was distanced (Greenberg, 1964: 131).

With regards to Atget's work as a whole, its chief significance is in the same treatment of the everyday objects of the city and elements of its architecture. It is these unassuming places and unpicturesque landscapes that have been described by Valentin (1928: 20-21), in one of the first ever reviews of Atget, as 'decidedly strange places where there appeared to be nothing of the slightest interest' until he photographed them. The surrealists thought of Atget's work as intriguing precisely because of these qualities - the use of the readymade, the strangeness and distance of perspective and choice of subject, and the everyday (see Walker, 2002: 88). It is this that Benjamin (1931: 518) defined as aura, the unique experience of a specific place - a 'strange weave of space and time: the unique appearance or semblance of distance, no matter how close it may be'. In his monograph on the city, surrealism and photography, Walker (2002: 88-96) describes an intriguing example of one of the four images of Atget's that was published in Andre Breton's La Révolution surréaliste:

This is one of his photographs of prostitutes; the woman is small in the centre of the frame, standing in front of a large doorway $[\ldots]$. Again, there is a connection between 
the image and the surrounding text by Réne Crevel, which is set in a seaside port peopled by, among others, prostitutes. However, the multicultural environment that Crevel evokes is very different from that depicted in the photograph, which is simply entitled "Versailles". Atget's bluntly factual caption had caused Man Ray some amusement at what he considered Atget's naivety. [...]

How Atget himself thought of such a structure can be surmised from the text accompanying a similar image in his own album L'Art dans le vieux Paris [The art of old Paris]: "Rue Charlot, 83 (3rd Arrt) - Hotel Marquis de Mascarini (disappeared). Splendid extension, wrought iron, of the Hotel staircase". The caption is tersely factual, with hints of delight (“splendid”) and regret (“disappeared”). (Walker, 2002: 91-92)

The examples of Atget's caption for the image and its 'terse factuality' is indicative of Atget's commitment to the old architecture of Paris, often being only parts of a building, that due to being in a state of disrepair would, if not documented, disappear from the urban landscape. Sramek (2013:19) points to the numerous instances in which Atget returned to certain sites that were undergoing or would go through demolition. Understood this way, his album Vieux Paris [Old Paris] is a project tinged with loss and the disappeared. Sramek (2013: 19) further asserts that while Atget would follow the progression of demolition of certain sites, he was not interested in photographing the new architecture in order to contrast it with the old. Moreover, the stark contrast of the descriptions in Walker's example (2002), and its interpretation, is often taken to imply a certain naivety in Atget's work, a taste for the outmoded, and a lack of aesthetic complexity. However, a different reading is possible and has been put into words first by Walter Benjamin. In keeping with Benjamin, Gilloch (1997: 123) has argued that the 'obsolete object reveals the truth of the fetishized commodity; the old-fashioned discloses the reality of the fashionable' in a dialectical manner - and it is this that the surrealists supposedly found appealing in Atget's work (Walker, 2002). According to Benjamin himself (who also linked Atget to the surrealists, going as far as calling him a proto-surrealist - Benjamin, 1979), this abstraction of elements of architecture, places, and objects of the everyday life of the city was a commendable invention by Atget (Benjamin, 1931: 518): 
When avant-garde periodicals like Bifur or Variete publish pictures that are captioned "Westminster," "Lille," “Antwerp," or "Breslau" but that show only details, here a piece of balustrade, there a treetop whose bare branches crisscross a gas lamp, or a gable wall, or a lamppost with a life buoy bearing the name of the town - this is nothing but a literary refinement of motifs that Atget discovered.

These motifs, as described by Benjamin, are something that often figures in the description of Atget's work. Hazan (2011: 359) talks of 'the series of door-knockers taken for maniacal decorators in search of "grand siècle" motifs, or the details of the buttresses and roofs of Saint-Sevèrin'. In another of the first reviews of Atget, Robert Desnos (1928: 16) describes the 'bourgeois homes, homes of workingmen, homes of luxury including that of Mlle. Sorel, the booths of street fairs, grocery store windows, barbershops, stairs, stocks of street merchants, etc'. Similarly, Sramek (2013: 22) lists the 'excised design details in the manner of Atget, who created many collections of door knockers, stairway railings and other such designed items'. Teige (1931: 316) emphasises Atget's failed career as a painter, while he also singles out 'the streets and corners of Paris, its byways, oases, and store windows - in short, the motifs [Atget] wanted to paint'.

However, from a more pronounced urban perspective, one can reflect on how much Atget's practice is interwoven with the city of Paris itself. Atget's Paris was Haussmann's Paris - a city which followed a consistent and continuous logic that combined both form and function, aesthetic sensibilities and capitalist interests, all the while resulting in a panoptic space that is structured on the basis of lines of sight. This was also true of the minute elements of the city - the railings, tree grilles, gas lights, lamp posts, façades, and benches were all standardised; as Vidler (2011: 100) comments - a 'bench in the Faubourg Saint Antoine was the same as that in the Champs-Elysée'. It is here that the documentary function of Atget's photographs can be found. As Greenberg has commented, photography works best when it is at its most transparent and 'lets the almost "practical" meaning of the subject come through' (Greenberg, 1964: 131). Atget did so by capturing a variety of architectural elements central to the urban space of Paris. As Nesbit (1998) has commented, he did so with particular viewers in mind, but most of his images included documentary information for multiple types of viewers - metalworkers, architects, urban planners, artists, surrealists, etc. By doing so, Atget, in fact, lived up fully to the phrase used by Pierre Mac Orlan (1929: 33) in introducing his work in the first ever publication - Atget: Photographe de Paris - 'a perfectly organized witness'. 


\section{The City as an Encounter}

The great cities of modernity were overwhelming for the senses. From Simmel to Benjamin, from Engels to Kracauer, numerous writers have noted that the city opened up for new encounters in the $19^{\text {th }}$ century. It was most overwhelming for sight - in a matter of minutes one would encounter strangers they would never see again, face numerous advertisements one could either notice or ignore, and inevitably deal with the spectacle of fashion. One had to learn quickly how to manage, how to avoid gazes, as well as how to attract or find them. Baudelaire stands as one of the authors who captured this experience in a manner that preserved the ambiguity inherent to this novel experience. His work is of great value to understanding the streets which Atget walked and documented.

It is easy to forget this character of the city - the many ways in which it is an encounter and a simultaneity. The L'homme armè (figure 4) photograph, taken c.1900 and acquired by the Victoria and Albert Museum (VAM) in 1903, has originally been labelled in the National Art Library, now part of the VAM Museum, in the categories of 'architecture' and 'ironwork', and has been labelled in the online catalogues as pertaining to the subject of: metal-work, canons, swords, grilles (barrier elements), storefronts, men, shop signs, and body armour ${ }^{6}$.

In order to understand the photograph, however, a different hermeneutic is necessary than simply listing the visual elements present in the image. As Barthes has noted, such a list would be a naïve analysis and it would lack any explanatory power (1977: 37). Walter Benjamin (1935: 6) has commented that Atget's photographs appear to depict a crime scene:

The scene of a crime 7 , too, is deserted; it is photographed for the purpose of establishing evidence. With Atget, photographs become standard evidence for historical occurrences, and acquire a hidden political significance. They demand a specific kind of approach; freefloating contemplation is not appropriate to them. They stir the viewer; he [sic] feels challenged by them in a new way.

What would it mean then to treat the 'L'homme armè' as an image of a crime scene, what would the crime be, and how would the image be able to reveal something to an observer? Even more so, what is the origin of the stir caused by Atget's photographs? 


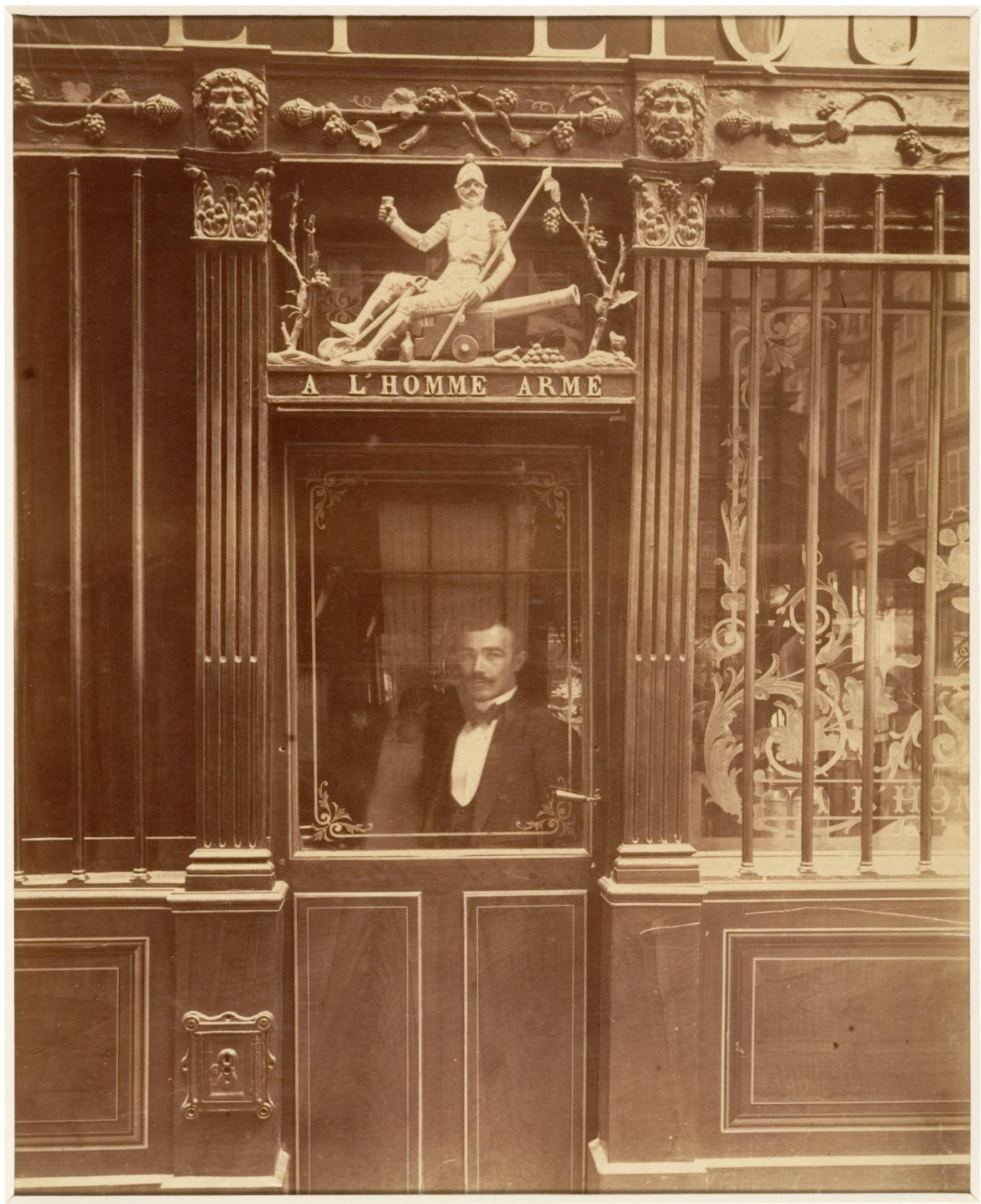

Figure 4 Cabaret de l'Homme Armé, 25 rue des Blancs-Manteaux by Eugène Atget, ca.1900. Gilman Collection, Purchase, Mrs. Walter Annenberg and The Annenberg Foundation Gift/MET Museum/WikiCommons.

There are many myths around Atget's photographs. First, that he didn't take photographs of people; in fact, he did include people occasionally in his streetscapes, and he also had a project documenting working people as well as a separate one that consisted of nudes. Second, he did not take photographs only in Paris. 
For example, there are photographs from trips to Switzerland. Third, although known for his empty streetscapes, Atget extensively documented a variety of objects such as railings, door-knockers, stonework, ironwork, and more. My goal is not to provide a singular hermeneutic of Atget, nor is it to explicate his entire body of work. Rather, I point here to an aspect of his work that exemplifies the tension of the urban encounter in the Paris of his day. Moreover, the encounters that Atget seems to have been interested in are ones of demystifying the very dynamism of the city - of stilling it, rendering it uncanny, making one confront it in a new light. Since 'Atget's work [...] should be read as one massive series' (Raymond, 2019: 50), taking a single photograph is one way of reading his work against the grain. A L'homme arme does this in a way that one cannot forget the invisibility of labour, rendering this very text an encounter of sorts.

\section{The Eyes of the Poor and the Anonymous Multiple}

In his influential discussion of cities, modernity, and the work of Baudelaire on Paris, Berman explores the prose poem 'The Eyes of the Poor' in some depth (2010). It is an influential poem, and, despite its brevity, it manages to touch on class conflict and privilege, modern social relations, and the urban environment of mid-Haussmannisation Paris. Baudelaire writes (2009: 51-52), quoted at length:

[...] In the evening, a bit tired, we wanted to sit down in front of a new café that formed the corner of a new boulevard, still strewn with debris and already gloriously displaying its unfinished splendors. The café was sparkling. The gaslight itself sent forth all the ardor of a debut and lit with all its force walls blinding in their whiteness, dazzling sheets of mirrors, the gold of the rods and cornices, chubby-cheeked page-boys being dragged by dogs on leashes, laughing ladies with falcons perched on their wrist, nymphs and goddesses carrying on their heads fruits, pies, and poultry, Hebes and Ganymedes presenting in out-stretched arms little amphoras filled with Bavarian cream or bi-colored obelisks of ice cream — all of history and all of mythology at the service of gluttony.

Right in front of us, on the sidewalk, a worthy man in his forties was standing, with a tired face, a greying beard, and holding with one hand a little boy and carrying on the other arm a little being too weak to walk. He was playing the role of nanny and had taken his children out for a walk in the night air. All in rags. The three faces were extraordinarily serious, and 
the six eyes contemplated fixedly the new café with an equal admiration, but shaded differently according to their age.

[...] Not only was I moved by this family of eyes, but I also felt a little ashamed of our glasses and our carafes, which were larger than our thirst. I turned my gaze toward yours, dear love, to read my thoughts there; I plunged into your so beautiful and so bizarrely gentle eyes, into your green eyes, inhabited by Caprice and inspired by the Moon, and then you said to me: "I can't stand those people over there, with their eyes wide open like carriage gates! Can't you tell the head-waiter to send them away?” [...] (emphasis added)

There are several important elements in the poem that can be used to reflect on the photograph by Atget. First, it should be noted that Baudelaire paints a clear image of the urban changes going through Paris in the 1860s, during which Paris Spleen was written. Notably, Baudelaire's writing is concerned both with the urban gaze of modernity, and the gaze on the urban (Rancière, 2017). Furthermore, the role of the gaze, or sight, for critical theory has been discussed in depth (see Gilloch, 2002). The new boulevards were the technology that opened up the space of the city to all its inhabitants, and more importantly created the space for the new bourgeois culture of cafés, in contrast to the old cafés being local to a neighbourhood (Berman, 2010; Haine, 1999). Second, the new café is the place of a large amount of ornamentation and luxury, revealing the new city to be not only going through increasing commercialisation and embourgeoisement of the new 'public' spaces, but also posits the problem of social interaction in such an environment. The ornamentation and luxury are not to be understood as mere details, but as key parts of the role that space has in mediating class conflict and privilege (see Kracauer, 1995; Reeh, 2004). The ornamented detail, the gold, mirrors, and gaslight (one can imagine intricately ornate railings and ironwork on the doorway) are both an effect of the new wealth and growth of the city, but also a medium for communicating class privilege and exclusivity. In Kracauer's terms (1995: 75), the ornamentation and luxury of the café can be seen as the epoch's 'inconspicuous surface-level expressions,' which, according to Gilloch (2015: 37), allows for 'the dialectics of depth hermeneutics - recognizing and reading surfaces as the essential manifestations of what lies below'. 
Baudelaire (2009), both in the title and the text, emphasises the role of the gaze in social interaction in the modern city. Both Benjamin and Kracauer argued that the modern city is increasingly based on vision; the sociologist Georg Simmel (1903) has also noted this development. As much as the ornamented interior of the new café is important it is only revealed to be class privilege through the encounter with the gaze of the 'family of eyes' (Berman, 2010). Rice (2000: 37) comments that Baudelaire's poem is:

$[\ldots]$ a scene of multiple and shifting perspectives: of viewpoints as unstable as a city that disappears and is rebuilt, and as isolated as the eye of a man or a woman behind a camera.

As Rancière argues (2017), this is indicative of modern urban experience, where Baudelairean 'modern beauty' is 'that of the anonymous multiple' (2017: 109, emphasis added). For Rancière, the notion of 'the anonymous multiple' is central to modern history and historicity. In other words, '[w]riting history and telling stories come under the same regime of truth' (2004: 38), but not in the sense that history is 'made up of stories', but rather that 'the "logic of stories" and the ability to act as historical agents go together' (2004: 39). For Rancière, this becomes evident in literature first, before it enters other fields such as photography, science, or history, namely:

an epoch and a society were deciphered through the features, clothes, or gestures of an ordinary individual (Balzac); the sewer revealed a civilization (Hugo); the daughter of a farmer and the daughter of a banker were caught in the equal force of style as an 'absolute manner of seeing things' (Flaubert). (2004: 32)

This, in turn, manifests itself into a shift from the great names and persons of history to the life of the anonymous', where one finds 'symptoms of an epoch, a society, or a civilization in the minute details of ordinary life' (2004: 33). As such, it is firmly located in a mode of visibility that revokes grandeur 'in favour of the interpretation of signs on the body of people, things, and civilisations' (2004: 34). However, in order to do this, the anonymous must become more than ordinary through this process:

the ordinary becomes a trace of the true if it is torn from its obviousness in order to become a hieroglyph, a mythological or phantasmagoric figure. This phantasmagoric dimension of the true, which belongs to the aesthetic regime of the arts, played an essential role in the formation of the critical paradigm of the human and social sciences. (2004: 34) 
It is with this phantasmagoric mode of truth and historicity in mind, that Rancière (2017: 110) notes a similar scene of spectatorship and spectacle to that of Baudelaire's poem:

$[T]$ he window that shows and hides, the encounter with singular beings whose faces bear a history but, since Balzac, have lost the power to tell it and the exchange of gazes that opens an infinite vanishing line in the everyday space of the city. It is important that the window first and foremost opens only onto a world of other windows, behind which stands, for example, that wrinkly woman leaning over something indefinable and whose face, clothing and confused gesture permit a story to be made up.

The gaze is at the centre of the scene above, in the same way it is in 'The Eyes of the Poor'. With Rice's photographic reference (2000) and Rancière's metaphoric 'window' (2017), the role of the gaze and its political effect can be applied through a hermeneutic of the photograph by Atget ${ }^{8}$.

First, the direct gaze of the person in it might make an impression to an observer of the photograph. However, it is important to note that the photograph was sold to the V\&A Museum as a document of 'ironwork' and 'architecture' - very much like the ornamented luxury of the café in the poem. According to Lederman (2008), a curator at the V\&A, the person in the photograph is a waiter, or the maitre d'. The photographic technology that Atget used means that the waiter would have had to stand still for a prolonged period of time (Nesbit, 1992a; 1998). Lederman (2008) also points out that other blurry silhouettes can be seen inside the cabaret/café; the fact that other people are invisible, while the waiter is visible, would, in turn, further solidify the reading that the person has the job of standing at the door in order to greet new patrons. It could also be added, that this reveals a difference at play that is not unlike the class conflict at the centre of Baudelaire's poem. Namely, the people moving inside the café are likely to be the patrons, the ones who are, in a commercial sense, free to move in the space, while the waiter is required to stand still and fulfil a function that is tied to the doorway (see Rizov, 2016). Also, it is important to note that Atget's labour directly mimics that of the waiter; in many of his images of shopfronts, it is common to see the photographer's still silhouette.

Understood this way, the meeting of the waiter's gaze is significant ${ }^{9}$. Upon inspection, the gaze of the waiter appears to be in tension with the architecture surrounding him. The waiter's presence appears coincidental. 
Furthermore, if one's understanding is based solely on the institutional inscription of the photograph as 'ironwork' and 'architecture', there appears to be a process of omission at play as well. His presence is not only coincidental, but not of value. Although not alike the 'family of eyes' exactly, and unlike Baudelaire's couple, the waiter is revealed as something else than the 'maitre d' of the poem; he is not simply the channel of power that can dispel the unwanted patrons of the café, rather - he is at the mercy of the same reifying logic of commercial relations that is mediated by the ornament. Put simply, the photograph transforms the very presence of the waiter into an ornament of the cabaret. In other words, the camera is not being used to represent anything, but only to present 'a salutary estrangement between [a person and their] surroundings'10 (Benjamin, 2002: 518), that is, nothing other than capitalist modernity (Emerling, 2012: 178).

Thus, on one hand, the gaze of the waiter and its role in the image, in addition to being understood as an example of the overlooked 'small elements of a building [... that make up an 'urban image'] ranging from grave railings and skylight and window latticework to banisters and balcony railings' (Reeh, 2004: 64-65). On the other hand, however, the reading of the photograph being proposed here can be understood as an intervention into the order of the image, and its determination of what is visible and meaningful. It is this perspective that I propose has been missing from the treatment of Atget's photographs. Understood this way, the waiter, his fixed nature (both as occupation and photograph), and his gaze can be seen as inherently political. For Rancière, politics is 'first and foremost an intervention upon the visible and the sayable' (2001: 21), as well as a transformation of the visible and sensible into a space 'for the appearance of a subject: i.e., the people, the workers, the citizens' (2002: 22). The reading of Atget's documentary photographs is a political act, and one that must allow for the subjects of Paris' urban reality to come through. As Edwards (2016: 52) has summarised Rancière's concept, the political significance of a photograph 'revolves around what is seen and what can be said about it, around who has the ability to see and the talent to speak'. This is even more significant considering the relationship that I have highlighted, following Lederman (2008), between work and visibility in the particular photograph. The worker is the one 'who has no time to do anything but his [sic] own work' (Rancière, 2005: 14), and whose work consists of 'a form of visibility that is equated to [...] public invisibility' (Rancière, 2005: 13). This leads to the worker ending up 'without being counted as part of the symbolic order of the city' (Rancière, 1992: 61). 
Furthermore, the photograph is not only a photograph, or only a document - it is not simply a 'surface' consisting of various visual elements such as ironwork, waiter, or sign - rather, it is an inscription of political realities such as social class. If one thinks back on Baudelaire's poem, the gaze constituted a communicative act - Baudelaire's lyrical 'I' was actively involved in reading the eyes of the family as it was gazing on the luxury of the café; the character of the poem was doing the same with regards to their lover. Thus, the gaze entails a relationship that is mediated by the material, ornamented reality of overlooked 'small elements $[\ldots]$ ranging from grave railings and [wrought iron] window latticework to banisters and balcony railings' that nevertheless create 'the distinctive character both of the individual buildings and of a city or region' (Reeh, 2004: 64-65). Rancière (2017: 112) has noted that the gaze has a clear mediational function:

The wealthy man's joy is miserly when it has not been infinitized by the poor man's gaze, stretched toward the café's lights and decorations.

It has to also be acknowledged that the person primarily implicated in the relationship of the gaze, and its distribution of the sensible is Atget himself; according to one institutional description (Art Insitute Chicago $^{11}$ ), the photograph 'also reflects, like a ghost, the likeness of the photographer himself ${ }^{12}$. The gaze of the waiter then can be made to reveal an interaction with the current observer of the photograph. This way, the interaction with Atget's photograph allows even the present viewer for a form of genuine experience of the modern city, described by Gilloch (2002: 101) as 'the fleeting, unexpected encounter with the stranger in the crowd' (also, see Gilloch, 1997: 143; also, see Simmel, 1903, on the urban figure of 'the stranger'). In a more in-depth reading in keeping with Benjamin's dialectics of seeing, the gaze of the waiter reveals his 'aura', making the interaction an authentic one. 'Aura' is defined by Gilloch (2015: 37) as 'the individual quality of the sitter which emanates from his or her eyes and which meets the gaze cast upon it'. This 'enduring silent conversation' is telling, since it speaks of Benjamin's claim (1935: 6) of 'a hidden political significance' in photographs that resists 'free-floating contemplation'.

An additional dimension could be added to the significance of the specific photograph - it is urban, shot from the street, and does not show the interior of the cabaret. This is in direct contrast to Atget's few photographs of bourgeois interiors. First of all, 'the bourgeois interior is a loathsome, desolate refuge from social activity in the public sphere' (Gilloch, 1997: 79). According to Gilloch (1997: 79, emphasis added), 
this is in keeping with the "hallmark of the modern bourgeoisie [of] the public denial of sensuality, of the reciprocity of gaze, of human interactions and relationships'. Prior to the invention of buses, railways and trams, according to Simmel, people 'had never been in a position of having to look at one another for long minutes or even hours without speaking to one another' (as cited in Benjamin, 2006b: 38). According to Benjamin (as cited in Gilloch, 1997: 140), the expansion of the interior (especially so in the arcades) was a means 'to minimize and destroy this disquiet'. Understood this way, the apparently intended documentary function of Atget's photographs is documenting more than the built environment of the city of Paris, but the social processes at play in his historical epoch as well.

\section{Conclusive Notes}

According to Fraser (1968: 205), Atget's photographs show his dedication to a project of documenting the city 'as a place in which one moves around, consumes things, seeks mental refreshment, and rest'. In other words, the photographs of various types of urban environments Atget documented the city in the form of 'urban images'. This theme encompasses shopfronts, doorkeepers, uninhabitated streets, and repetitive vistas leading to churches. Despite the fact that Atget's work was rarely concerned with a 'peopled city', his work captures the 'urban images' of the city 'as they impinged on someone actually living in [Paris] in an ordinary daily way' (Fraser, 1968: 204-205). Kracauer (as cited in Frisby, 2013: 138) has added that it is such a view of the city that affords a perspective which does not take away agency from people's everyday life in the city and shows an experience 'that is hardly harmed by the architectural perspective of the king and the enlightened haute bourgeoisie'. Fraser (1968: 205) further points to the few instances in which Atget took candid photographs of Parisian workers and claims that these images can be seen as artefacts of the epoch, tinged by a feeling of 'quaintness' that is inevitably accompanied by loss and nostalgia. Further to this point, Sramek (2013: 22) points out that, in his photographic practice Atget 'moved along the street, framing at an angle to focus on a building or a particular doorway and $[\ldots]$ he included interior courtyards' as well. According to Sramek (2013: 22), Atget's interest was not in the street plan, but in buildings - 'façades, architectural and decorative details'. This, in turn, has resulted into a documentary project that captures 'the configuration of streets' (Sramek, 2013; 22), but does so with an effect that is 'a continual visualization of the walking areas that [Atget] presents' (Fraser, 1968: 207). It is this that has allowed Atget to provide, what Susan Buck-Morss has referred to, as 'the phenomenological hermeneutics' of the street (Buck-Morss, 
1989:3). For Benjamin (1999), even 'corsets, feather dusters, red and green colored combs, old photographs, souvenir replicas of the Venus di Milo, collar buttons to shirts long since discarded' are remnants that can act as 'concrete, historical referents' (Buck-Morss, 1989: 4). In this text, Buck-Morss's definition (1989: 3) of Benjamin's 'phenomenological hermeneutics' has been applied to the 'old photographs' taken by Atget as much as their content (architecture, urban space, or merchandise).

In fact, the presence of people can demonstrate this 'phenomenological' or lived aspect of the spaces and objects that Atget documented. In a dialectical manner, the hectic nature of modern urban life is rendered immobile in the photographs, just as much as the social life of the space, its people, are rendered like objects trapped in an imposing architectural environment. The city becomes an image in the same way that people are rendered anonymous, multiple objects. It has been noted that this is an aesthetic development (Rancière, 2017). As such, it is ultimately a matter of knowledge production and social distinction. In other words, the politics of rendering the city's inhabitants as objects and ornamentation becomes expressed in more than a simple desire to document everything against the fears of entropy (Edwards, 2009), but in a desire to render visible the new form of urban experience in order to control it. As Rancière notes, the 'anonymous multiple' is on the verge of speaking - Atget reveals this to be so. More importantly, however, Atget's images make the argument for the need to hear the anonymous' voice. 


\section{References}

Abbott, Berenice (1964). The World of Atget. New York: Berkley Windhover.

Art Institute Chicago (no date). Cabaret de l'Homme Armé, Rue des Blancs-Manteaux, 1900. Permanent Collection Label, available at < http://www.artic.edu/aic/collections/artwork/223184/print>.

Barthes, Roland (1977). Image Music Text. London: Fontana Press.

Barthes, Roland (2001). Camera Lucida: Reflections on Photography. New Library Press.

Baudelaire, Charles (2009). Paris Spleen. Middletown, Connecticut: Wesleyan University Press.

Benjamin, Walter (1931[2005]). Little History of Photography. In Selected Writings Volume 2, Part 2, 1931 -

1934. Transl. by Rodney Livingstone and Others. London: The Belknap Press of Harvard University Press.

Benjamin, Walter (1979). One-Way Street and Other Writings. London: Suhrkamp Verlag and Lowe \& Brydone Printers.

Benjamin, Walter (2002). The Arcades Project. London: Harvard University Press.

Benjamin, Walter (2006a). Selected Writings, Volume 4, 1938-1940. Ed. by Howard Eiland and Michael W. Jennings. London: Harvard University Press.

Benjamin, Walter (2006b). The Writer of Modern Life: Essays on Charles Baudelaire. Ed. Michael W. Jennings. London: The Belknap Press of Harvard University Press.

Benjamin. Walter (1969 [1935]). The Work of Art in the Age of Mechanical Reproduction. In Illuminations, ed. Hannah Arendt. New York: Schocken Books.

Berman, Marshall (2010). All that is Solid Melts into Air: Experiences of Modernity. London: Verso Books. Buck-Morss, Susan (1989). The Dialectics of Seeing: Walter Benjamin and the Arcades Project. London: MIT Press.

Campbell, David (2014). Integrity of the Image (Report). World Press Photo Academy.

Desnos, Robert (1928). Spectacles of the Street - Eugène Atget. In: Christopher Phillips (ed) Photography in the modern era: European documents and critical writings, 1913-1940. Metropolitan Museum of Art. 
Durden, Mark (2013). Fifty Key Writers on Photography. London: Routledge.

Dyer, Geoff (2012). Eugène Atget: Mute Witness. Aperture 206, pp.66-73.

Edwards, Elizabeth (2009). Salvaging our Past: Photography and Survival. In: Elizabeth Edwards and Christopher Morton (eds) Photography, Anthropology and History: Expanding the Frame. Abingdon: Ashgate.

Emerling, Jae (2012). Photography: History and Theory. London: Routledge.

Fraser, John (1968). Atget and the City. The Cambridge Quarterly, 3 (3), pp.199-233.

Freund, Giselle (1980). Photography and Society. Boston: David R. Godine Publisher.

Frisby, David (2013). Fragments of Modernity: Theories of Modernity in the Work of Simmel, Kracauer and Benjamin. London: Routledge.

Gilloch, Graeme (1997). Myth \& Metropolis: Walter Benjamin and the City. Cambridge: Polity Press.

Gilloch, Graeme (2002). Walter Benjamin: Critical Constellations. Cambridge: Polity Press.

Gilloch, Graeme (2015). Siegfried Kracauer: Our Companion in Misfortune. Cambridge: Polity Press.

Greenberg, Clement (1964). Four Photographers. The New York Review of Books, 23rd Jan 1964, available at [http://www.nybooks.com/articles/1964/01/23/four-photographers/].

Grierson, John (1966). Grierson on Documentary. Ed. Forsyth Hardy. Berkeley: University of California Press.

Haine, W. Scott (1999). The World of the Paris Café: Sociability among the French Working Class, 17891914. Baltimore: Johns Hopkins University Press.

Hambourg, Maria Morris and Szarkowski, John (1982). Eugène Atget, 1857-1927. Museum of Modern Art. Harvey, David (2005). Paris, Capital of Modernity. London: Routledge.

Hazan, Eric (2011). The Invention of Paris: A History in Footsteps. London: Verso Books.

Huddleston, Sisley (1928). Bohemian Literary and Social Life in Paris: Salons, Cafés, Studios. London: George G. Harrap. 
Hudgins, Nicole (2013). Neither Pictorialism nor Documentary Photography: The Camera's Uses and the Struggle for Self-Expression in Industrial Cities, ca.1857-1907. Photography and Culture, 6 (1), pp.7-40.

Jameson, Fredric (2016). The Detections of Totality. London: Verso Books.

Kracauer, Siegfried (1960). Theory of Film: The Redemption of Physical Reality. New York: Oxford University Press.

Kracauer, Siegfried (1995). The Mass Ornament: Weimar Essays. Transl. and ed. Thomas T. Levin. London: Harvard University Press.

Lederman, Erica (2008). Eugène Atget. In: Juliet Hacking (ed) Photography: The Whole Story. New York: Prestel Verlag.

Loughlin, Michael (2001). Gustave Hervé's Transition from Socialism to National Socialism: Another Example of French Fascism? Journal of Contemporary History, 36 (1), pp.5-39.

Lugon, Olivier (2006). 'Documentary': Authority and Ambiguities. In: Maria Lind and Hito Steyerl (eds) Green Room: Reconsidering the Documentary and Contemporary Art \#1. Sternberg Press.

Mac Orlan, Pierre (1929). Preface to Atget Photographe de Paris. In: Christopher Phillips (ed) Photography in the modern era: European documents and critical writings, 1913-1940. Metropolitan Museum of Art.

MacFarlane, Dana (2010). Photography at the Threshold: Atget, Benjamin and Surrealism. History of Photography, 34, pp.17-28.

Nesbit, Molly (1992a). 'In the Absence of the Parisienne...' In: ed. Beatriz Colomina and Jennifer Bloomer (eds) Sexuality \& Space, pp.307-326. New York: Princeton Architectural Press.

Nesbit, Molly (1992b). Atget’s Seven Albums. New Haven: Yale University Press.

Nesbit, Molly (1998). Photography and History: Eugène Atget. In: Michel Frizot (ed) A New History of Photography. Köln: Könemann.

Newhall, Beaumont (1937). Photography, 1839-1937. Museum of Modern Art.

Perego, Elvire (1998). The Urban Machine: Architecture and Industry. In: Michel Frizot (ed) A New History of Photography. Köln: Könemann. 
Rancière, Jacques (1992). Politics, Identification, and Subjectivization. October, 61, pp.58-64.

Rancière, Jacques (2004). Introducing Disagreement. Angelaki, 9 (3), pp.3-9.

Rancière, Jacques (2005). From Politics to Aesthetics? Paragraph, 28 (1), pp13-25.

Rancière, Jacques (2011). The Politics of Aesthetics: The Distribution of the Sensible. Transl. by Gabriel Rockhill. London: Continuum.

Rancière, Jacques (2017). The Lost Thread: The Democracy of Modern Fiction. Transl. by Steven Corcoran. London: Bloomsbury Academic.

Reeh, Henrik (2004). Ornaments of the Metropolis: Siegfried Kracauer and Modern Urban Culture. London: MIT Press.

Raymond, Claire (2019). The Photographic Uncanny: Photography, Homelessness, and Homesickness. London: Palgrave Macmillan.

Rice, Shelley (2000). Parisian Views. London: MIT Press.

Rizov, Vladimir (2016). The Dialectics of Documents: The Case of the Real and the Fantastic. The Luminary, 7.

Rizov, Vladimir (2018). Photographic Cities and the Photographic Production of Space: Eugène Atget's Paris and Thomas Annan's Glasgow. PhD thesis, University of York.

Rizov, Vladimir (2020). The Photographic City: Modernity and the Origin of Urban Photography. City, 23 (6), pp.774-791.

Rosler, Martha (2004). Decoys and Disruptions: Selected Writings, 1975-2001. London: MIT Press.

Rubin, James (2008). Impressionism and the Modern Landscape: Productivity, Technology, and Urbanization from Manet to Van Gogh. London: University of California Press.

Sekula, Allan (2016). Photography against the Grain: Essays and Photo Works, 1973-1983. London: Mack. Simmel, Georg (1903). The Metropolis and Mental Life. In: Gary Bridge and Sophie Watson (eds) The Blackwell City Reader. London: Wiley-Blackwell. 
Solomon-Godeau, Abigail (1991). Photography at the Docks: Essays on Photographic History, Institutions, and Practices. Minneapolis: University of Minnesota Press.

Sontag, Susan (1979). On Photography. Milton Keynes: Penguin.

Sramek, Peter (2013). Piercing Time: Paris after Marville and Atget 1865-2012. Intellect Books.

Szarkowski, John (1985). Modern Times. Musem of Modern Art.

Tagg, John (1988). The Burden of Representation: Essays on Photographies and Histories. Minneapolis: University of Minnesota Press.

Teige, Karel (1931). The Tasks of Modern Photography. In: Christopher Phillips (ed) Photography in the modern era: European documents and critical writings, 1913-1940. Metropolitan Museum of Art.

Valentin, Albert (1928). Eugène Atget. In: Christopher Phillips (ed) Photography in the modern era: European documents and critical writings, 1913-1940. Metropolitan Museum of Art.

Vassallo, Jesus (2014). Documentary Photography and Preservation, or The Problem of Truth and Beauty. Future Anterior, 11 (1), pp.14-33.

Vidler, Anthony (2011). The scenes of the street and other essays. New York: The Monacelli Press.

Walker, Ian (2002). City Gorged with Dreams: Surrealism and Documentary Photography in Interwar Paris. Manchester: Manchester University Press.

Warner, Marina (1993). The Paris of Phantoms. The New York Times, 11th Apr 1993, available at [https://www.nytimes.com/1993/04/11/books/the-paris-of-phantoms.html].

\footnotetext{
${ }^{1}$ Photographers such as Berenice Abbott (Campbell, 2015: 256), Man Ray, Brassaï, Henri Cartier-Bresson, Walker Evans (Campbell, 2015: 256), and August Sander (Szarkowski, 1985) are reported to have been inspired by him.

${ }^{2}$ André Breton used one of his photographs for the cover of the first surrealist manifesto - La Révolution surréaliste (MacFarlane, 2010; also, see Walker, 2002).

${ }^{3}$ Atget provided reference photographs, a lucrative aspect of his photographic work, to many Parisian artists (Freund, 1980).

${ }^{4}$ A discussion of the two styles can be read in Allan Sekula's influential essay (2016) on the topic.

${ }^{5}$ Some clarifying notes on the history of documentary photography are necessary. Tagg (1988: 8), when discussing the field of practices that Grierson first identifies as documentary, comments:
} 
it was entirely bound up with a particular social strategy: a liberal, corporatist plan to negotiate economic, political and cultural crisis through a limited programme of structural reforms, relief measures, and a cultural intervention aimed at restructuring the order of discourse, appropriating dissent, and resecuring the threatened bonds of social dissent.

It is this historical fluctuation in the use of the term and its reflection in photographic practice and images that has led Solomon-Godeau to assert that the term documentary photography does not possess an ontological definition, but rather a historical one (1991). In other words:

[the term 'documentary' and its] permutations are testimonial to the way photographic uses, and the meaning ascribed to them, are constantly in flux, repositioned and reoriented to conform to the larger discourses which engender them (SolomonGodeau, 1991: 170).

${ }^{6}$ This list points to an aspect of Atget's body of work that is to do with the archive and the production of knowledge, something beyond the scope of this article. To explore this properly, one would need to examine particular archival institutions as well as undergo thorough analysis of more than one photograph (for this, see Rizov, 2018).

${ }^{7}$ It should be noted that, for Benjamin (2006: 72), this crime was inextricably tied to the city and its spaces: No matter what traces the flaneur may follow, every one of them will lead him [sic] to a crime. This is an indication of how the detective story, regardless of its sober calculations, also participates in the phantasmagoria of Parisian life. It does not yet glorify the criminal, though it does glorify his adversaries and, above all, the hunting grounds where they pursue him [sic]' (emphasis added; also, see Gilloch, 1997: 141)

${ }^{8}$ For a literary example of this approach done in a different context, see Jameson (2016: 44-56); also, Gilloch (2002) on Baudelaire and Benjamin; also, Berman (2010) on Baudelaire only.

${ }^{9}$ Raymond (2019: 47) has recently commented on Atget's photographs as encounters with commodities, such as mannequins in shopfronts gazing back through the photograph.

10 The quotation in its entirety: 'Empty is the Porte d'Arceuil by the fortifications, empty are the triumphal steps, empty are the courtyards, empty, as it should be, is the Place du Tertre. They are not lonely, merely without mood; the city in these pictures looks cleared out, like a lodging that has not yet found a new tenant. It is in these achievements that Surrealist photography sets the scene for a salutary estrangement between man [sic] and his [sic] surroundings. It gives free play to the politically educated eye, under whose gaze all intimacies are sacrificed to the illumination of detail.' (Benjamin, 2002: 518).

${ }^{11}$ The full quotation being: "He focused here equally on the emblem of "the armed man" - a title (and a tavern) dating to the medieval crusades, rendered in word and image to assure its familiarity to a partially illiterate clientele - and on the maitre d', who gazes back through a glass window that also reflects, like a ghost, the likeness of the photographer himself.'

${ }^{12}$ Dyer (2012b: 66), in reference to Atget's influence on Walker Evans, comments the following: 'One of many instances of the way that Atget seems entirely embodied in his photographs - which were, Evans noted, "the projection of Atget's person" - this tendency of the pictures to be somehow about themselves, to be, in a nonderogatory sense, self-regarding, is part of their allure. (Those occasional glimpses of the reflected camera in shop windows are, in this respect, clues, evidence.)' 